\title{
The Origins of the Spanish Fury at Antwerp (1576): A Battle Within City Walls
}

\section{RAYMOND FAGEL}

Raymond Fagel is Lecturer of Early Modern History at the History Institute of Leiden University. He specialises in the contacts between Spain and the Low Countries during the sixteenth century. Between 2014 and 2019 he directed the nwo research program Facing the enemy. The Spanish army commanders during the first decade of the Dutch Revolt, 1567-1577. He is the author of Cristóbal de Mondragón. De goede Spanjaard uit de Opstand (Zierikzee 2020) and Nonnen verdreven door geuzen (Hilversum 2019, with Joke Spaans), and co-editor of Early modern war narratives and the Revolt in the Low Countries (Manchester 2020, with Leonor Álvarez Francés and Beatriz Santiago Belmonte).

\begin{abstract}
The Spanish Fury at Antwerp is one of the most emblematic events in the history of the Revolt in the Low Countries; it has become a symbol of blind violence and of cruelty against defenceless women and children. However, the story is not as simple as has been accounted for in historiography. Was it a mutiny that turned into the plundering of the city, or was it a battle within city walls between professional soldiers that subsequently led to pillaging? This question will be answered by going back to the earliest descriptions of the events and by charting and comparing the evolution of successive narratives in detail. The analysis will combine textual and visual sources, such as pamphlets, correspondences, chronicles, theatre plays, historical works, and engravings.
\end{abstract}

Keywords: Spanish Fury, Antwerp, Dutch Revolt, Habsburg Spain, military history, war narratives

DOI 10.18352/emlc.130 - URL: http://www.emlc-journal.org

Publisher: Stichting EMLC, supported by Utrecht University Library Open Access Journals | The Netherlands Copyright: The Author(s). This work is licensed under a Creative Commons Attribution-NonCommercial 4.0 International License. 


\section{The Origins of the Spanish Fury at Antwerp (1576): A Battle Within City Walls}

\section{RAYMOND FAGEL}

On 3 November 1576, the Antwerp merchant Jan van der Meulen wrote to his brother Andries in Cologne about the tense situation in their home town. Four days later, Jan's letter arrived in the hands of his brother. On the back of the letter, Andries (or his secretary) wrote: 'As the Spanish Fury had taken place on 4 November.' And indeed, on that very day, troops from the Antwerp citadel had attacked and subsequently plundered the city. Jan would not live to tell the tale. The short annotation on the letter proves that news from the attack had already arrived in Cologne by 7 November, but also that it was almost directly described as the Spaensche furie (Spanish Fury). ${ }^{1}$

This Spanish Fury at Antwerp is one of the most emblematic events in the history of the Revolt of the Low Countries, and probably within the history of early modern warfare in Europe. ${ }^{2}$ In his 1977 monograph on the Dutch Revolt, Geoffrey Parker even called it 'the holocaust of Antwerp'. ${ }^{3}$ It has become a symbol of blind violence and of cruelty against defenceless women and children. Because of the burning of the beautiful new Renaissance town hall, it can also be considered a crime against human culture. Peter Arnade dedicated considerable attention to it in his study on the political culture of the Dutch Revolt, calling it 'the greatest example of Spanish villainy against the civic realm'. ${ }^{4}$

However, the story is not as simple as has been accounted for in historiography. Two interrelated problems lie at the heart of this. In the first place, there is uncertainty about the magnitude of the subsequent plundering and sacking of the city. At the time, the States-General counted 18000 deaths, while an Antwerp burgher at the same time mentioned 7000 mortal victims. Though Geoffrey Parker in his Dutch Revolt settled on some

1 Leiden University Library (herafter UBL), ATH 182, Jan van der Meulen to Andries van der Meulen, Antwerp, 3 November 1576: 'Alsoo de Spaensche furie den 4. November geschiedt was'. Also cited in Pietersma, 'Jan van der Meulen'. I would like to thank the anonymous reviewers and the editorial board for their valuable comments on an earlier version of this article, as well as conference audiences in Amsterdam, Bruges, and Santander, where parts of this article were first presented.

2 Buchanan, 'Massacre', 6.

3 Parker, Dutch Revolt, 178.

4 Arnade, Beggars, 243. 
8000 deaths, more recently a much lower number of some 2500 dead civilians is being used by historians. ${ }^{5}$

This article will engage not with the number of casualties, but mostly with a second problem, related to the interpretation of the events. If we scrutinise the origins and the characterisation of the Spanish Fury of Antwerp, what was it precisely? Was it a mutiny that turned into the plundering of the city, or was it a battle within city walls between professional soldiers that subsequently led to pillaging? The generally acknowledged presence of Spanish mutineers at the scene further complicates this question. Modern international historiography tends to speak of a violent and unorganised mutiny, while earlier sources and local historians in Antwerp seem to prefer the idea of an organised battle. ${ }^{6}$

This question will be answered by tracing the earliest descriptions of the events and comparing the evolution of successive narratives in detail, using a combination of textual and visual sources, such as pamphlets, correspondences, chronicles, theatre plays, historical works, and engravings. Three closely interconnected contentions will be made in the course of this article. Firstly, that the oft-used pamphlet on the events attributed to the Tudor author and soldier George Gascoigne is a reworking of a Dutch language pamphlet; secondly, that the famous Hogenberg engraving on the Spanish Fury does not hold up well against evidence from the pamphlets and modern historical knowledge; and thirdly, that recent scholarship tends to frame the events in an unbalanced way.

When Jan van der Meulen wrote to his brother on 3 November 1576, the Low Countries, and even more so the city of Antwerp, found themselves in a state of turmoil. Governor-General Luis de Requesens had unexpectedly died on 5 March 1576, and his death had created a power vacuum, though the Council of State in Brussels tried to take charge of government directly. When, after more than one month, a letter from Philip II confirmed the leading position of the Council of State, two antagonising groups had been formed in the Low Countries: the Council of State on the one hand, under leadership of the Duke of Aarschot, and a Spanish faction at the other, led by councillor Gerónimo de Roda and Sancho Dávila, the governor of the Antwerp citadel. By July 1576, the situation had turned into complete chaos. On the $25^{\text {th }}$, Spanish mutineers - soldiers left for years without pay had occupied the Flemish town of Aalst, while unsatisfied armed burghers in Brussels had taken over power in their city. Under influence of this Brussels movement, the Council of State outlawed the Spanish mutineers, while the Spanish military commanders were convinced that the rebellion of the Brussels burghers constituted the real problem. On 4 September, all members of the Council of State in Brussels were apprehended by troops from the States of Brabant. A few days later the States of Brabant called for a meeting of the States-General in Ghent. Though formally this was the privilege of Philip II as lord of the Low Countries, it was soon to be endorsed by the meanwhile freed Council of State under the initiative of Aarschot. On 22 September, the decree against the mutineers was

5 Van der Lem, Opstand, 112, 245; Marnef, 'Towns', 98; Parker, Dutch Revolt, 178. See also UBL, ATH 1303, Henrick de Hazen to Andries van der Meulen, Antwerp, 11 November 1576.

6 Against the general idea of mutinies being violent and unorganised, modern historians have shown that most Spanish mutinies were well-organised events: Parker, 'Mutiny'; Sherer, “"All of us”'. 
extended to include all Spanish troops in the Low Countries and the States-General had started organising their own army. ${ }^{7}$ The country was at war.

In the city of Antwerp, power was divided between the civil governor Frédéric Perrenot, Lord of Champagney, and the governor of the citadel Sancho Dávila. Champagney supported the government of King Philip II, but was a fierce opponent of the Spanish military presence. An agreement was signed stating that the city would not allow any soldiers from the States-General to enter, while Dávila would not let the mutineers enter the citadel. Escalation, however, proved unavoidable. While Sancho Dávila was gathering loyal troops in the citadel through its outside gate, Champagney allowed an army of the States-General to enter the city. William of Orange's troops were also approaching Antwerp. It was at this critical point in time, on 3 November 1576, that Jan van der Meulen wrote his last letter to his brother Andries.

\section{Word and Image}

The two single most used sources on the history of the Spanish Fury are the newsprints by the Brabantine engraver Frans Hogenberg and the famous pamphlet The Spoyle of Antwerpe, attributed to English author George Gascoigne and published within a month of the events taking place. ${ }^{8}$ Between August 1576 and April 1577, Hogenberg, working from the city of Cologne, published a series of some twenty engravings related to recent events in the Low Countries. Several of these engravings, all related to the Spanish Fury, were shortly afterwards re-used in a combination print containing seven images, centred around a map of the city of Antwerp (fig. 1). This combination print contains only a title and a few dates, and avoids using the word 'fury'. ${ }^{9}$ The Hogenberg prints were from the beginning of the Revolt part of an intense paper war waged over the interpretation of the events within the public realm. Marianne Eekhout has stated that not only did his prints possess a high news value, but that they also presented the first imaginings of the stories about the cruelties that had taken place in the Low Countries. ${ }^{10}$

In his recent book on the Hogenberg prints, Ramon Voges demonstrates how Hogenberg attempted to suppress his Protestant outlook on the events in favour of a generally impartial view based on the available information, in order to create the largest market possible for his prints. However, to achieve his goal Hogenberg needed to establish a clear dichotomy between the Netherlanders and the Spaniards, which he achieved 'by opposing a Spanish community of perpetrators with a Netherlandish community of victims'. ${ }^{11}$ We find in his engravings 'a comprehensive anti-hispanic enemy image' with the Spanish as

7 Santiago Belmonte, 'The year of the Furies'; Janssens, Brabant in het verweer, 269-323.

8 Fagel, 'Gascoigne's The Spoyle'.

9 Horst, Opstand, 173-175; Voges, 'Macht', 6o.

10 Eekhout, 'Furies', 250. See also Voges, 'Power', 139; Voges, 'Macht', 67-68.

11 Voges, Auge der Geschichte, 284. 


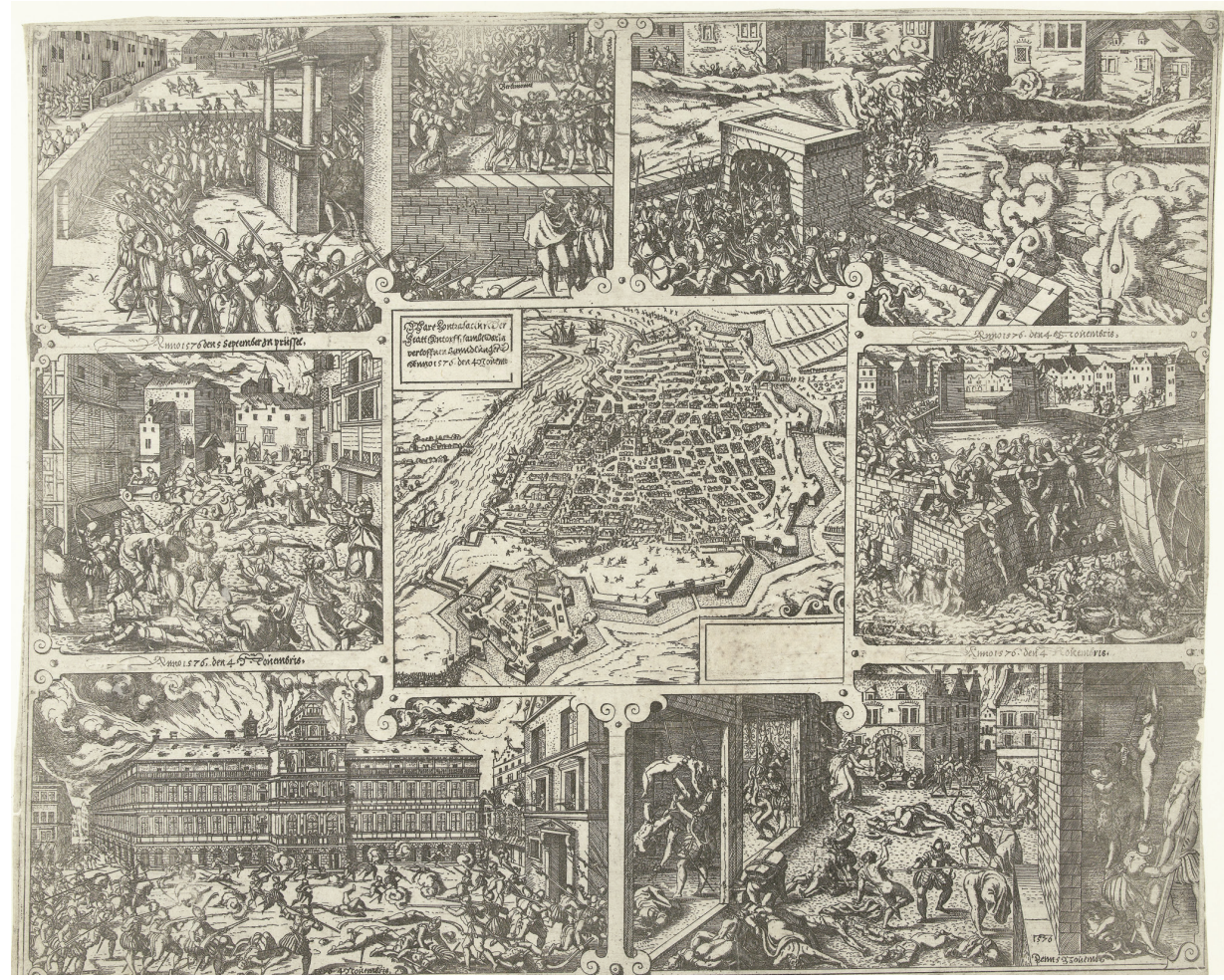

Fig. 1. The Spanish Fury at Antwerp in 1576. Attributed to Frans Hogenberg, Ware kontrafactur der statt Antorff sambt darin verloffnen hanndlungen anno 1576 den 4 novemb., 1577, etching, 37,1 $\times 45,4 \mathrm{~cm}$, Amsterdam, Rijksmuseum.

'a national community of perpetrators of violence'. ${ }^{12}$ Regarding the Spanish, his policy of impartiality did not function at all. This is fundamental for our understanding of his depiction of the events in Antwerp.

The original engravings, which were produced individually, included poems which hinted at a specific interpretation of events. Hogenberg blamed the burghers of Antwerp for being prone to excessive luxury, and described the brutal actions of the Spaniards as well-deserved punishment for their decadent behaviour. ${ }^{13}$ The combination engraving does not include such texts. The setting of the two images at the top in particular - the soldiers entering the Council of State in September, and the troops pouring out of Antwerp citadel on 4 November - seems to indicate that in their new guise these prints were intended to emphasise the results of military violence against the innocent.

12 Voges, Auge der Geschichte, 188, 226; Pollmann, 'Eine natürliche Feindschaft', 89-93; Benedict, Graphic history, 145-147, 168, 190.

13 Horst, Opstand, 175. 
Though Gascoigne's The Spoyle of Antwerpe is undoubtedly the most famous text on the Spanish Fury, it is fundamentally a reworking of a pamphlet from the Low Countries converted by the gifted English author into a personal description of the events that had taken place in Antwerp, and as such much more agreeable to read than the impersonal original. The fact that The Spoyle is considered to be one of the earliest early modern ego-documents makes its origin even more interesting. Within historiography, the original Dutch pamphlet has rarely been used, though it is clearly a first-rate source on the events. It was directly translated into French and subsequently from French into German. ${ }^{14}$

Gascoigne, who had served both as a soldier and as an agent of the English government, was present in Antwerp during the Fury. He left the city on 12 November, reaching London about a week later. The Spoyle was published within two weeks of his arrival. He must have taken a copy of the original pamphlet with him from Antwerp, meaning that it must have been published within days of the events themselves. ${ }^{15}$ This anonymous Dutch pamphlet was written by someone very critical of the actions of the Spanish soldiers, as the title clearly shows: The true description of the taking of Antwerp and of the inhuman and very gruesome murder, fire, sack, and the unheard violation of women and girls by the Spanish and their adherents, on November 4, 1576, and several days thereafter, written by one who had been present himself. ${ }^{16}$

About half of Gascoigne's text comprised a literal translation of about 90 percent of the original Dutch, to which he added minor details to add personal colour. The other half of The Spoyle consists of paragraphs from his own pen. His supposed personal meeting with a Walloon trumpeter is nothing more than a transformation of the original, impersonal Dutch text. The same happened when writing about the burning of the town hall. Gascoigne took the element of moedwillig, the deliberate air of malice displayed in the pamphlet, as an incentive to put words into the mouths of some Spanish soldiers. The original pamphlet mentioned that 'they also have deliberately burned the impressive town hall with all the monuments and the old and noble records and memories, saying that it was there that the reunions had taken place of all evil council and all treacherous attacks' ${ }^{17}$ In Gascoigne's words this was turned into an account in the first person with a considerable amount of pathos: 'I have talked with sundry of them, and demaunded why they would command that the Townehouse should be burned? And their aunswer was, because it was the place of assembly where all eveyll counselles were contrived. ${ }^{18}$ The following dry observation of the Dutch pamphlet was also skilfully turned into a dramatic scene by Gascoigne: 'During as long as twenty days after the fury, all Walloons they could find were killed, and even many others whom they thought were of that nation, without any deliberation. ${ }^{19} \mathrm{He}$ dramatized this as: 'At least all the world wyll beare mee witnes, than

14 Brieve et veritable Histoire; Warhaffige und erbermliche Zeitung.

15 Fagel, 'Gascoigne's The Spoyle', 2-3.

16 Warachtige beschrijvinghe.

17 Warachtige beschrijvinghe: 'Ende daer beneven hebben sy moetwillich verbrant dat statelicke stadthuys met alle die monumenten ende olde loeffelicke recorden ende gedachtenissen seggende dat daer de vergaderinghe hadde gheweest van alle boose raedt en verraderische aenslagen.'

18 Gascoigne, Complete works, II, 597.

19 Warachtige beschrijvinghe: 'Daer en boven wel twintich daghen nae de furie al wat sy voor Walen conden vinden, moestent met den doodt becoopen alsoo dat vele andere uut suspicie van dier natie te wesen noch mede vermoort werden sonder eenich advys oft audientie.' 
ten (yea twenty dayes) after, whosoever were but poynted at, and named to bee a Wallon, was immediatlye massacred without furder audience or tryall. For mine owne part, it is wel known that I did often escape very narrowly, because I was taken for a Wallone. ${ }^{20}$

\section{The Battle}

A comparison of Hogenberg's combination print with the Dutch pamphlet on the events of the first day reveals so many differences that one might even wonder whether they are indeed describing the same series of events. Where the image in the top right-hand corner of Hogenberg's print shows a simple low entrenchment made by the inhabitants of the city to defend themselves against the citadel, the text speaks of two entrenchments, one of them being even as high as the length of a pike. However, the work on the barricades was not completely finished when the attack started. Another clear difference is the way the troops from the citadel attacked the city. Hogenberg's engraving shows the cavalry pouring out of the citadel through one gate and entering the city through one small street. According to the pamphlet, the troops from the citadel, some five thousand men, gathered in the large open space in front of it. They formed six infantry squadrons, with the cavalry behind them, and the German troops along the river: this was an army preparing for battle.

Conversely, the engravings display little fighting. We can detect some people behind the low entrenchment, but instead of weapons they are holding what appears to be shovels. They must represent the inhabitants of Antwerp working on the trenches the day before, maybe finishing the second line of defence. According to the pamphlet, the trenches were bravely defended by Walloon and German troops, holding out for hours, and it was only the persistence of the attackers and the fact that the defenders did not receive any fresh troops, that allowed the Spanish soldiers finally to break through. The cavalry followed behind the infantry. It was a real battle with a huge number of casualties. Further on in the pamphlet, we read that next to the entrenchments lay heaps of corpses, piled up as high as a man. A letter by an Antwerp burgher also recalled the heavy fighting, 'many being killed on both sides' ${ }^{21}$ The Calvinist minister Pierre L'Oyseleur de Villiers spoke in a letter dated 6 November of 'the defeat of the army of the Estates'. ${ }^{22}$ The engravings, however, tell a story that omits the battle within the city in its entirety.

The text also explains why the defenders did not get reinforcements. The Walloons and the Germans had thought that the entrenchments were too high for the Spanish troops to overcome, so they had left the front lines and had gone into the city where they visited the inns. When the news of the attack arrived, they did not even believe it to be true. The pamphlet blames the disaster on a lack of discipline amongst these troops. This version of events is supported by the memoirs of Governor Champagney, who wrote that the soldiers

20 Gascoigne, Complete works, II, 597.

21 Geeraert Janssen to Jacop Cool, Antwerp, 14 November 1576, in Hessels (ed.), Abrahami Ortelii, 148: 'Soo datter seer vele over beyden syden, doot gebleven zyn'.

22 Villiers to Francis Walsingham, Middelburg, 6 November 1576, in Kervyn de Lettenhove (ed.), Relations politiques, IX, 4: 'la desfaitte de l'armée des Estats'. 


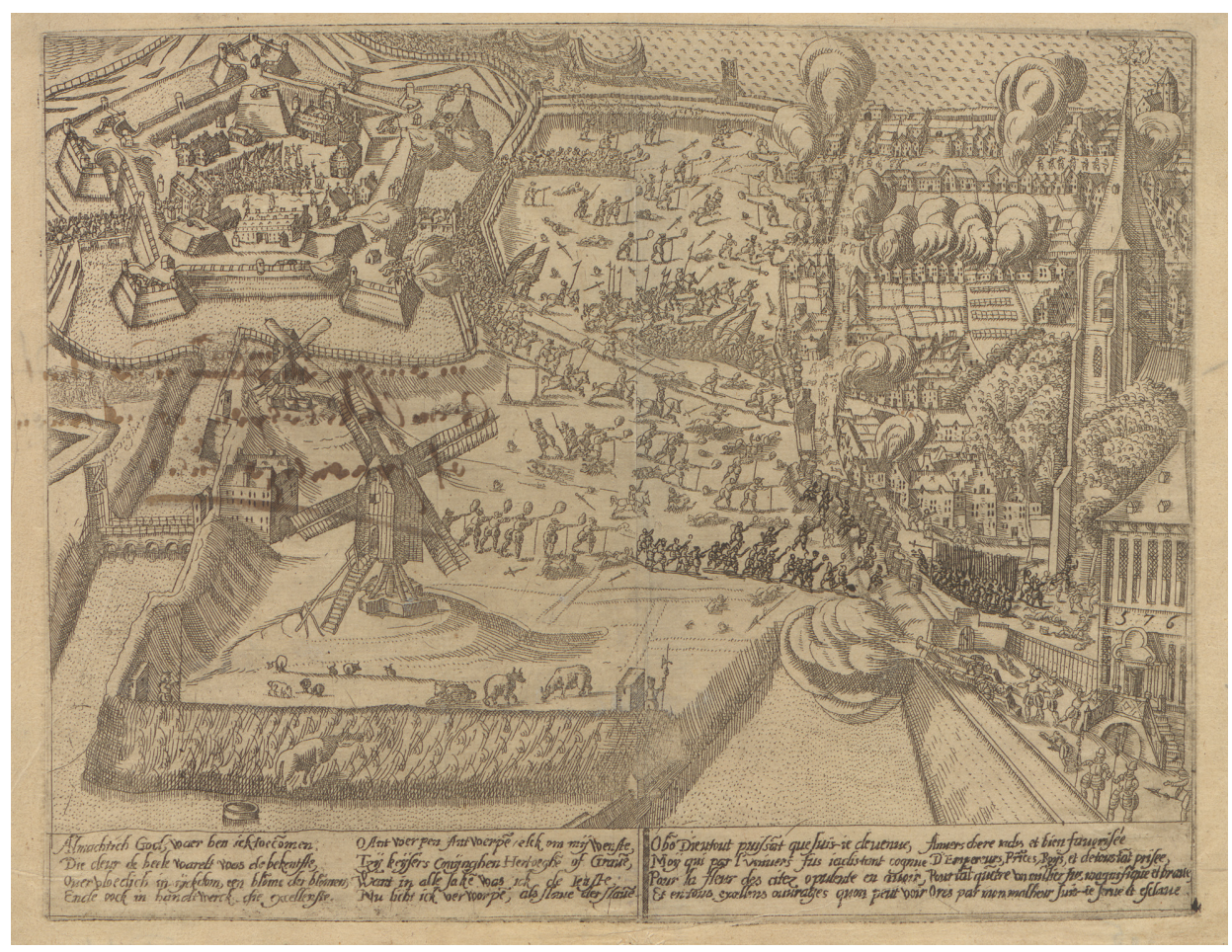

Fig. 2. Johannes Portantius, Spanish troops crossing the barricades in front of the citadel and starting their attack, ca. 1576, 21,5 × 28,3 cm, Antwerp, Museum Plantin-Moretus.

had refused to stay in the trenches, against his orders, and had gone into the city looking for good houses to sleep in, even plundering them. ${ }^{23}$

There exists another engraving, by Johannes Portantius from Ghent, a geographer and scientist who was living in Antwerp at the time. His print does show the infantry attack from the citadel and offers a much better idea of the fighting on the barricades (fig. 2). Here we see many more troops defending the city against attack. Piet Lombaerde, who wrote an article on Portantius' engravings on the Spanish Fury, describes them as much more spontaneous, realistic, and lively than the Hogenberg prints, the latter sometimes demonstrating clear signs of serial production. Portantius's engravings accord much more with the 1576 pamphlet on the attack on the city from the citadel. ${ }^{24}$ Hogenberg clearly did not make use of the pamphlet as a source of information for his engravings on the Spanish Fury, even though within months of the events a German translation of the pamphlet had been published in Cologne, the city where he had resided since his departure from the Low Countries. It seems implausible that Hogenberg remained completely unaware of this very different narrative almost immediately available in several editions and languages, 
implying that in the case of his engravings on the Spanish Fury the message was more important than a truthful rendering of events. ${ }^{25}$

Once they had overrun the trenches, the Spanish troops killed everybody they encountered, but the pamphlet describes it as an organised attack. They first occupied all the street corners with musketeers, but houses were set on fire only after they had been plundered; this was done by the muchachos, the young helpers of the soldiers. ${ }^{26}$ Again, this does not resemble the engravings where there is no resistance from within and the Spanish soldiers occupied themselves merely with looting and harassing the women of the city. But where were the men from Antwerp, as the engravings show few men present in the streets? Again, the text offers a clue as to their whereabouts: 'The burghers all stayed in their houses, and some of them in front of their doors with their muskets, of whom many fought until death.' Once more, the engravings omitted an important element of the fighting, namely the active role of the Antwerp burghers.

But why were these men standing in front of their houses? This is explained by one of the most important articles on the events, written by military historian Etienne Rooms in $1971 .^{27}$ He made clear how the very important body of civil guards, with hundreds of men, had received orders to stay at home until summoned to go to one of the designated gathering places in the city. However, the summons never came, and many a civil guard must have stood ready, musket in hand, prepared to defend himself, his family, his house, and his property. This implies that the Spanish attackers encountered isolated armed civil guards who must have been easy prey for the experienced army soldiers. It also means that the streets of Antwerp were not only filled with innocent women and Spanish soldiers as on the engravings, but that actual fighting was taking place. However, many men decided to run and flee the fighting. The pamphlet includes the previously mentioned story of the Walloon trumpeter who tried to stop everybody from running away.

The Spanish soldiers encountered German soldiers at the market square of the city, in front of the town hall. The Germans tried to surrender, shouting 'Lieve Spaniarden, lieve Spaniarden', a wording in Dutch even Gascoigne rendered in the original language. But they were killed without mercy by the 'dear Spaniards,' and were left lying dead in their armour, with burned heads, arms, and shoulders. On the engravings we can also identify some defenders at the market square, but these are mostly running away. So again in the images we cannot discern much fighting between soldiers.

A closer examination of the town hall in the combination print reveals some thin lines that seem to indicate the presence of figures in the central part of the building on the first floor. When we compare this with the more detailed individual engraving by Hogenberg, we see that the original engraving contained many more defenders - at least eleven peopleand some of them even had smoke coming out of their weapons, proving they were actually firing their arms. This is the only time the engravings represent military violence between the attacking Spaniards and the defenders, but now it is the pamphlet that depicts the events differently in offering a non-military explanation: 'They have 
intentionally burned the stately town hall with all the old and noble records and memories, saying that it was there that the reunions had taken place of all evil council and all treacherous attacks. ${ }^{28}$

As mentioned before, Gascoigne even claims to have heard this explanation from the Spanish soldiers themselves, but this is clearly part of his appropriation of the text. However, Peter Arnade follows this lead and states that the attack on the town hall was a symbolic deed. According to him, the soldiers would otherwise have ignored the 'great Renaissance-style stadhuis in the city's center, and would not have set fire to the archives of privileges and other documents it housed. [...] They made the attack on the town hall the centerpiece of the fighting. ${ }^{29}$ The use of the burning town hall as a symbol can also be found in the visual arts. ${ }^{30} \mathrm{~A}$ letter to Philip II dated 6 November, written by Spanish councillor Gerónimo de Roda who was present in the citadel at the time, explained the events differently: 'As from the town hall and other houses they severely damaged our men, causing them almost to retreat, these places were set on fire and burned. ${ }^{31}$ Roda gives a military explanation for the burning of the building that accords with the images of Hogenberg.

There is no doubt that it effectively was a battle within city walls. Military historian Etienne Rooms offers a comparison of the troops involved in the attack, counting some 4000 infantry and 800 cavalry on the royal side, against 9000 infantry and 1200 cavalry within the city, without including the large body of armed civil guards. According to him, it was 'a battle of which the outcome was not sure at all' ${ }^{32}$ This fits well with the pamphlet that even considers it the work of God, 'because otherwise it would have been impossible that so few soldiers would have been capable of gaining a city with so many inhabitants and with so many soldiers.'. ${ }^{33}$

\section{The Sack}

The battle in the city took several hours. Directly afterwards, the attack turned into the pillaging of Antwerp, with thousands of plundering and looting soldiers. The engravings focus mostly on this aspect of the Spanish Fury, while the text of the Dutch pamphlet dedicates relatively little space to these events. The text mentions 17000 victims, both from the Low Countries and foreigners, religious and lay people, women and children. The soldiers

28 Warachtige beschrijvinghe: 'Daer en boven wel twintich daghen nae de furie al wat sy voor Walen conden vinden, moestent met den doodt becoopen alsoo dat vele andere uut suspicie van dier natie te wesen noch mede vermoort werden sonder eenich advys oft audientie.'

29 Arnade, Beggars, 251.

30 Eekhout, 'Furies'. A woodcut by Antonie van Leest shows a woman attacked by two Spanish soldiers against the background of a burning town hall. An engraving by Hans Colaert de Oude diplays the burning town hall in the centre of the image. Horst, Opstand, 175-179; Boone, 'Dutch Revolt', 370.

31 Perrenot, Mémoires, 195-201: 'Pource que la maison de ville et autres voisines faisoyent grand dommage à nous gens, dont quasi ils se retirèrent, on y mit le feu, et les leur bruslat on.'

32 Rooms, 'Nieuwe visie', 51, 53.

33 Warachtige beschrijvinghe. 
spared nobody, and the streets were full of dead bodies and there were streams of blood. There were also many dead horses, and taken together this caused a terrible smell that plagued everyone still living in the city. The women and the daughters were raped, and parents were forced to get their daughters out of their hiding places in the convents in order to share a bed with two Spaniards. The soldiers were looking for as much money as possible, harassing the foreign merchants of the city into paying a ransom. Not everyone was as lucky as the Portuguese merchant Luis Alvares Caldeira, who found two Portuguese soldiers who could be paid off easily. ${ }^{34}$ In a letter written on 14 November, a burgher of Antwerp stated that 'I have never been so near death as I was at that time near being murdered, shot or burned'. ${ }^{35}$ Though plundering was an accepted part of the strategic punishment of disobedient cities, in the case of Antwerp the violence was clearly excessive. ${ }^{36}$

The most illustrative sentence on the looting from the pamphlet can also be found in Gascoigne's version, which notes that 'every Dom Diego must walk jetting up \& down the streetes with his harlotte by him in her cheine and bracelettes of gold'. ${ }^{37}$ The famous merchant Bourse was turned into a casino. Although the engravings focus on the cruel behaviour of the Spaniards with many naked women, the still rather empty streets of the engravings do not adequately capture the atmosphere that must have reigned in the city. However, the real situation was also most surely not as apocalyptic as reflected in an anonymous painting of the Spanish Fury. Though this painting was based on two of Hogenberg's engravings, its character is completely different. The fact that two priests are quietly watching the terrible scene indicates that the painter was not as careful as Hogenberg in avoiding the religious divide..$^{3}$ It is, however, not the intention of this section to analyse all available documents and narratives on the sacking and plundering of the city, but merely to evaluate the information on the sack offered by the engravings and the pamphlet.

The engravings showing so much violence against women can be put within the wider framework already addressed by Voges. ${ }^{39}$ Netherlandish drama also focused on violence towards innocent women by foreign soldiers. As Amanda Pipkin confirms, 'more often than not, in these depictions the Dutch are husbands, fathers, sheep attacked by wolves. [...] They are not depicted as heroic soldiers standing firm against a martial threat. ${ }^{{ }^{\circ}}{ }^{\circ}$ Within the early modern image war, it was a confrontation between Spanish soldiers and Netherlandish burghers. Peter Arnade puts the same phenomenon within the wider frame of a

34 Luis Alvarez Caldeira to Simón Ruiz, Antwerp, 25 November 1576, in Vázquez de Prada, Lettres marchandes, III, 225 .

35 Geeraert Janssen to Jacop Cool, Antwerp, 14 November 1576, in Hessels (ed.), Abrahami Ortelii, 148: 'Want ick myn leven nooyt so naer myn doot geweest hebbe, als ic op dien tyt geweest ben, van vermoort, doerschoten, oft verbrant te syn.' See also UBL, ATH 1303, Henrick de Hazen to Andries van der Meulen, Antwerp, 11 November 1576 .

36 Parker, 'Etiquette', 155-157; Soen, ¿Más allá', 56-58.

37 Gascoigne, Complete works, 597.

38 Anonymous, The Spanish Fury, ca. 1585, canvas, 137 x $162 \mathrm{~cm}$, Antwerp, Museum aan de Stroom, inv. Av.1980.014; Eekhout, 'Furies', 250-253.

39 Voges, 'Macht', 65.

40 Pipkin, 'They were not humans', 242. See also Pipkin, Rape. 
'language of civic order and virtuous citizenship'. ${ }^{41}$ The engravings by Hogenberg and the compilation print accord perfectly with this idea, while the battle within city walls does not.

It is also noteworthy that the engravings do not focus on the aspect of mutiny that is so present in the work of modern historians, either. The 1576 pamphlet does mention the mutineers, albeit only very briefly at the beginning. The first reference is to their arrival from Aalst, explaining they were led by their leader, the electo. Then the pamphlet offers the famous anecdote of the mutineers not wanting to rest before attacking the city: 'They swore an oath not to eat, nor drink or rest before they could do the same quietly and easily within the city of Antwerp.'42

We can find this anecdote in many different sources, such as the Histories of the Revolt by the Dutch Calvinist historian P.C. Hooft, first published in 1642. Hooft's last mention of the mutineers is when their electo died during the first wave of the attack on the trenches. From that moment onwards, as in the pamphlet, the Histories no longer differentiates between mutineers and ordinary soldiers. ${ }^{43}$ Hooft still describes most of the actual fighting, also mentioning Spanish royal troops that were not part of the mutineers, but the larger part of his text is dedicated to the sack of the city. This constitutes the real shift when compared to the narrative of the 1576 pamphlet: the complete series of events was still present, but the focus had changed from the battle to the sack.

The same holds for John Lothrop Motley's classic work from the nineteenth century, The Rise of the Dutch Republic, in which he generally follows Hooft's narrative, also describing the fighting but putting emphasis on the sack. He offers even more gruesome details and states that 'never was there a more monstrous massacre, even in the blood-stained history of the Netherlands. [...] The Spaniards seemed to cast off even the vizard of humanity.' According to Motley, the Spanish Fury even claimed more victims than the 1572 Saint Bartholomew's Day massacre in Paris. ${ }^{44}$ In his work, Motley wanted to emphasise the heroic struggle for freedom of William of Orange and the Dutch, and this epic needed the Spanish as villains. This was further supported by the fact that Motley's stance was very anti-Catholic. ${ }^{45}$

The character of the narrative had been quite different at the time of the events. The author of the 1576 pamphlet still found praise for the Spanish troops and their military qualities, even including the story of a Spanish colonel who saved the life of the rebellious Count of Egmont by risking his own life. Gascoigne was also very positive about the military qualities of the Spanish soldiers, writing that 'Caesar him selfe had never any suche souldiours'. But he subsequently criticised their behaviour after victory: 'Their daily trade in spoiling hath made them the cunningest ransackers of houses, and the best able to bring a spoyle unto a quicke market, of any souldiours, or mastertheeves that ever I heard of.' ${ }^{46}$

41 Arnade, Beggars, 259; Boone, 'Dutch Revolt', 355. See also García Cárcel, Demonio, 211.

42 Warachtige beschrijvinghe.

43 Hooft, Alle de gedrukte werken, IV, 469-470.

44 Motley, The rise, II, 637, 639-640. The first edition was published in 1856.

45 Verheul, Atlantische pelgrim, 125, 169, 166, 177.

46 Gascoigne, Complete works, 599; Geeraert Janssen to Jacop Cool, Antwerp, 14 November 1576 (in Hessels (ed.), Abrahami Ortelii, 146), mentions that the Spaniards 'fought very courageously'. 
This alteration in appraisal of the warlike qualities of Spanish soldiers is to be understood against the backdrop of the development of Protestant historiography between the seventeenth and the nineteenth centuries. The military aspects of the event were still present, but were coloured by the so-called Black Legend, turning the Spanish into a cruel and inhuman race. ${ }^{47}$ The presence of the mutineers in these texts is acknowledged at the beginning of the description, but as soon as the electo died during the first attack, the element of mutiny disappears. These authors did not need to put a specific emphasis on the mutineers, as all Spaniards were considered cruel and violent by nature.

\section{The Mutiny}

The question that remains is how and where the characterisation of the Spanish Fury as an attack by mutineers originates. The most obvious place to direct our gaze is Geoffrey Parker's well-known article on the mutineers during the Revolt, 'Mutiny and discontent in the Spanish army of Flanders'. In this article, based on a conference paper given in 1972, a still relatively young Parker boldly stated that 'the mutineers stormed the city and sacked it'. ${ }^{8}$ However, in his 1977 book on the Dutch Revolt, Parker decided to downplay this description: 'On the same day the Spanish forces in and around Antwerp, together with some German units, prepared to deliver an all-out attack on the city. [...] The Spaniards attacked at dawn.' ${ }^{49}$ In his more general book on the Revolt written five years later, then, the mutineers had clearly lost prominence.

Nonetheless, the idea of an attack by mutineers continues to be repeated and reassessed by modern historians, such as the aforementioned Peter Arnade in his book on the civic language of the citizens of the Low Countries during the Revolt:

The mutineers struck early Sunday morning, pouring out of the citadel and across the esplanade, easily breaching Champagney's unfinished fortifications. The Aalst electo Navarese held aloft a flag with the Virgin on one side and Christ crucified on the other and was cut down as his men clashed with the small units of Walloons and Germans willing to fight...$^{50}$

The wording not only gives a central role to the mutineers and especially to their chosen leader, the electo, but it also seems to take Hogenberg's image of the soldiers pouring out of the citadel as a matter of fact. It diminishes the importance of the defence (easily breached; small units) and turns the Spanish primarily into defenders of the Catholic faith. Another example can be found in an article by Judith Pollmann and Erika Kuijpers, in which the mutineers are prominent and the military character of operations is again suppressed. ${ }^{51}$ Emily Jo Peters even turned the mutiny and the sack of the city into exactly the same event, writing of 'the mutiny of the Spanish troops in Antwerp - called the Spanish Fury'. ${ }^{2}$

47 Martínez Luna, Ondraaglijk juk; Soen,'Más allá', 49-51.

48 Parker, 'Mutiny', 118.

49 Parker, Dutch Revolt, 178.

50 Arnade, Beggars, 248-249.

51 Kuijpers and Pollmann, 'Why remember terror?', 176, 179.

52 Peters, 'Den gheheelen loop', 47. 
Also, Ramon Voges found it necessary to correct Frans Hogenberg because he did not pay attention to the aspect of mutiny in his prints: 'The fact that the soldiers were mutineers is not recognized.' 53 These examples can be easily multiplied, and are not meant to criticise specific authors, but to illustrate that the idea of a violent mutiny has, since Parker's interpretation of the events, continued to gain momentum within historiography.

A 1982 study by the British hispanist Ann Mackenzie concluded that two seventeenth-century playwrights from England and Spain writing on the Antwerp Fury had their history completely wrong. These plays described the attack as premeditated while according to the author it was 'more through accident than design'. She also extended her argument to the sources of these two plays. Both the Spanish chronicler Bernardino de Mendoza, an officer of the Spanish army present in the Low Countries at the time, and the English author and eyewitness George Gascoigne also focussed on a battle within the city, and thus they all had it wrong. ${ }^{54}$ It seems very plausible, then, that Mackenzie's interpretation was based on Parker's article. ${ }^{55}$

The mutineers do play a significant role in the Spanish play she studied, El saco de Amberes, which is attributed to Francisco de Rojas Zorrilla and dated to around 1630$1640.5^{56}$ During these years, the Count-Duke of Olivares propagated the qualities of the Spanish army under Philip II in his attempt to reorganise the army and to promote Spanish unity against the Dutch enemy.57 The author puts emphasis on the relationship between the Spanish commander Sancho Dávila and the mutineers under their electo Juan de Navarrete. In the play, Sancho is an exemplary soldier who keeps on trying to convince the mutineers to come to his rescue. Towards the end of the play, they do indeed arrive at the gates of the citadel and a dialogue between the two protagonists follows:

Sancho: ¿Quién llama?
Navarrete: Los de Alost.
Sancho: ¿Y con qué intento?
(¿si acaso les ha animado
lo que anoche les previne?)
¿Venís a que se amotine
la gente que me ha quedado?
Navarrete: No es de tan infame ley,
la acción que nos ha movido
Sancho: ¿Pues que es lo que os a traído?
Navarrete: Ganalle a Amberes al Rey,
pues con hecho tan valiente,
nuestra misma afrenta cessa. ${ }^{58}$

Sancho: ¿Quién llama?

Navarrete: Los de Alost.

\author{
Who is calling? \\ Those of Aalst. \\ With what intention? \\ (Maybe you are animated \\ by what happened last night?) \\ Have you come to make mutineers \\ out of the people that are left to me? \\ There is no bad intention \\ behind the reason for our arrival. \\ So then, why have you come? \\ To win Antwerp for the king, \\ because with such a brave endeavour \\ we can make up for our affront.
}

53 Voges, 'Power', 139; Voges, 'Macht', 67-68.

54 Mackenzie, 'Study', 287; Fagel, 'Furia Española'.

55 Mackenzie, 'Study'.

56 Sanz Camanes, 'Relaciones', 978.

57 Rodríguez Pérez, 'Amotinado', 246.

58 Rojas Zorrilla, Saco. I have used the copy preserved in Toledo, Biblioteca de la Junta de Castilla La Mancha, inv. 1-862. 
The aspects of honour and a common identity belonging to the Spanish nation are essential to the play. At the end of the play, the mutineers and their electo are proven to be heroes and true Spaniards by their fighting for king and country. ${ }^{59}$ Both in the play and in the chronicles, Sancho led the mutineers into the citadel on the morning of the attack. According to military chronicler Bernardino de Mendoza, they were offered an opportunity to rest and eat, but the mutineers wanted to start the fighting immediately: 'They

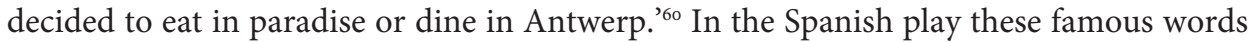
were rendered as 'we will eat in Antwerp or dine with Jesus Christ'. ${ }^{61}$ We see how the rather general anecdote from the pamphlet on the eagerness of the mutineers to start the attack without resting later on received a more elaborate form with a religious point, and most importantly, one which transcended historical sources.

In the play, it is Sancho Dávila who finally decided to open the gates to the city and thus initiated the attack, and this seems more than plausible. The mutineers had agreed to help out the commander and his troops within the citadel, but they still had not been paid their wages, the original cause of their mutiny. It was therefore decided that they were to be allowed to fight under their own electo and under their own banners. However, they were organised within the same squadrons as the other Spanish troops, and it was an organised attack under Sancho Dávila as their general commander. The mutineers formed a considerable part of the attacking forces, but it was not a mutiny. Seen from the Spanish side, it was a miracle that the Spanish had been able to overcome their differences and join forces against a common threat. The Spanish mutiny story, with loyal and honourable mutineers, stands completely opposed to the mutiny story found in the writings of Dutch and English authors.

From Spanish official letters, we learn that Gerónimo de Roda and Sancho Dávila had to defend themselves for carrying out the attack, and on 9 November, the newly arrived Governor-General of the Low Countries, Don Juan of Austria, did not mince words when addressing Sancho Dávila in a letter: 'Señor Sancho Dávila, the revolt that has taken place in Antwerp has given me great pain and it would be worse if I knew it has happened because of you or because of the Spanish soldiers there present.' ${ }^{62}$ It is clear that neither the king nor the new governor-general was happy with the brutal sacking of the richest city of the Low Countries. Though the punishment of disobedient cities had been policy from the times of the Burgundian dukes, the lords of the Low Countries could not afford to destroy one of their own main cities. They preferred a balanced policy, combining punishment with reconciliation. However, seen from the side of the burghers of Antwerp, the events fit well within the tradition of urban rebelliousness as studied by Marc Boone and others. ${ }^{63}$

59 Rodríguez Pérez, 'Amotinado'.

6o Mendoza, Comentarios, 85: 'Resueltos de comer en el paraíso o cenar en la villa de Amberes.'

61 Rojas Zorrilla, Saco, 31-32: 'Vamos a comer a Amberes o a cenar con Iesu Christo.'

62 Pidal y Salvá, 'Documentos', 138: 'Háme dado, señor Sancho de Avila, mucha pena la revuelta que en Amberes ha acaecido y mucho mayor sería se entendiese que por causa suya, ó de la gente española que ahí está, hubiese sucedido.'

63 Soen, 'Más allá', 67; Marnef, 'Towns', 94; Boone, 'Destroying', 14, 32; Boone, Dutch Revolt', 360. 
Five days later, Sancho explained to the new governor how the citadels of Ghent and Valenciennes had been attacked by troops from the States-General and that those in Antwerp had now succeeded in avoiding a similar attack. If they had not attacked the city, the forces of the city would have attacked the citadel. Their actions are presented as a kind of pre-emptive strike. 'When you receive all the information, you will understand that our people had been forced to act for their own health and safety,' Sancho wrote. ${ }^{64}$

We also possess a letter of Gerónimo de Roda to King Philip II, dated 6 November, a mere two days after the attack, and thus written while the plundering was ongoing. ${ }^{65}$ The experienced royal councillor related how the forces of the city had let in German soldiers paid by the States-General and that they had started to build entrenchments against the citadel, even installing pieces of artillery. The Spanish from the citadel had attacked these entrenchments for the first time before the arrival of the mutineers. We can find references to this earlier attack in the work of Spanish chroniclers such as Antonio Trillo, but also in an anonymous English pamphlet. Trillo suggests that the earlier attack gave the Spanish the idea that an overall attack on the whole city might be feasible. ${ }^{66}$ In his letter, Roda informs the king that just before the attack he had issued an ordinance stating that nobody was allowed to sack the city, enter into the houses, or hurt women or children. ${ }^{67}$ All soldiers had pledged obedience to this ordinance before attacking the city. Stating that the soldiers had simply not obeyed his orders is clearly a way of excusing himself for the violence. ${ }^{68}$ Even if the story was true, Roda knew perfectly well that this ordinance would not and could not be obeyed by the soldiers.

Conspicuous in their absence are any references to the mutineers. Roda mentions only once that they were fighting under their own banners and electo until they were paid, but neither Roda nor Sancho Dávila attempted to blame the mutineers for the excesses of violence in their official letters. Even when Roda stated that he had not been able to control the soldiers, he did not defend his own case by stating that many of them had officially still been mutineers. What Roda and Dávila seemed to be doing was to emphasise the victorious battle under their leadership and to downplay the negative story on the sacking, and for this it was better not to focus on the mutineers. And, quite logically, we also never find the idea that they had allowed the plundering in order to pay off the mutineers and the other soldiers. ${ }^{6}$ However, the royal councillor was not ambiguous at all as to the presence of mutineers when conversing with the English ambassador Thomas Wilson and looking for excuses for the violence. As Wilson reported, 'the sowldiours of Alost wer adventuriers, had no capitaynes, desperate persones, and woulde not bee ruled, by any proclamation or commandement that cowlde bee geaven or made'.$^{70}$

64 Sancho Dávila to Juan de Austria, Antwerp, 14 November 1576, in Pidal y Salvá, 'Documentos', 141: 'Cuando sea informado hallará que nuestra gente ha sido forzada por su salud y defensa haberse hecho lo sucedido procurando siempre de evitarlo.'

65 Perrenot, Mémoires, 195-201.

66 Lancaster, 'Larum for London', 461-462; Trillo, Historia, 298.

67 According to Génard, Roda was responsible for the events in Antwerp: Génard, 'Furie espagnole', $460-461$.

68 Perrenot, Mémoires, 198-200.

69 Parker, 'Etiquette', 157.

70 Thomas Wilson to the Privy Council, 19 November 1576, in Kervyn de Lettenhove (ed.), Relations politiques, IX, 42. 


\section{The War}

When explaining to Don Juan the reasons behind the attack, Sancho Dávila made mention of the attacks on the citadels of Valenciennes and Ghent. These urban citadels were hated by many burghers as symbols of excessive state power..$^{71}$ At the time, the Low Countries were in great turmoil, and everywhere people had taken up arms. It is impossible to dwell on the events in Antwerp without including this broader picture. Besides Ghent, the rather understudied events in Maastricht are also fundamental for reaching a general understanding of Antwerp. The Spanish Fury of Maastricht, as it is also called, took place on 20 October 1576 as a reaction against the imprisonment of commander Francisco de Montesdoca by some of the inhabitants of the city. It ended in a victory of the royal army, the killing of many civilians, and the plundering of the city. For the States-General the connection between Maastricht and Antwerp was obvious. In their letter of 6 November, they complained to Philip in that 'the Spanish soldiers present in the Low Countries have first taken, plundered, and burned the city of Maastricht, with the death of many burghers and inhabitants, and then in the same way they invaded, occupied, burned, sacked, plundered, and ransomed the [city of Antwerp]'..$^{2}$

In his memoirs, Governor Champagney also recalled warning the people in Antwerp to beware 'that the same that has occurred in Maastricht will not happen in Antwerp'.73 Gerónimo de Roda alludes to the same idea in his letter to Philip II of 6 November, observing that 'with the success of Maastricht, this city is now fearing the worst'. ${ }^{74}$ It seems very plausible that news of the events in Maastricht would have reached Antwerp within days. Such news would have most certainly terrified the Antwerp population, as they imagined what might happen if the soldiers of the citadel entered the city.

Conversely, Ghent offers a completely different story. The royal garrison in the citadel in Ghent had already been under attack by the troops of the States-General since the middle of September. ${ }^{75}$ The defenders would finally surrender on 11 November, an event also to be found in one of Hogenberg's engravings. In the Antwerp citadel, Sancho Dávila and Gerónimo de Roda must have known what was happening in Ghent, as they could still receive news from outside. They - and maybe also the soldiers - must have realised that they could suffer the same fate. Sancho Dávila would afterwards also explain their attack as a pre-emptive strike. ${ }^{76}$ In short, on the eve of 4 November, the inhabitants of the city and those within the citadel were possibly terrified of each other, and the examples of Maastricht and Ghent offered no solace.

71 Boone, 'From cuckoo's egg'.

72 States-General to Philip II, Ghent, 6 November 1576, in Génard, 'Poursuites', 129: 'Les gens de guerre espaignolz estants par deça, après avoir surprins, saccagé et bruslé partie de la ville de Maestricht, avec meurtre de grand nombre des bourgeois, manans et habitans d'icelle, ont pareillement hostilement envahy, occupé, bruslé, saccagé, brandschatté et rançonné la [ville d'Anvers]'.

73 Perrenot, Mémoires, 130: 'Se donner à garde que le mesme n'advint en Anvers qu'estoit advenu à Mastricht.' 74 Roda to Philip II, Antwerp, 6 November 1576, in Perrenot, Mémoires, 195: 'Avec le succès de Mastricht ceste ville s'a mis en extrême peur.'

75 Boone, 'From cuckoo's egg'.

76 Sancho Dávila to Juan de Austria, Antwerp, 14 November 1576, in Pidal y Salvá, 'Documentos', 141. 
In addition to the broader historical context discussed in the previous section, research on the Spanish Fury also has to include matters of a more personal nature, focusing on the individuals involved. It is important to be aware of the festering personal feud between the Lord of Champagney, the governor of the city, and Sancho Dávila, the governor of the citadel. According to Governor-General Luis de Requesens, Champagney could never come to an understanding with Sancho Dávila or any other army commander. 'Sancho Dávila, without offending anybody, is the best soldier the king has at his disposal in the Low Countries, and you can only blame him for his violent passion towards Champagney, whereas Champagney possesses a terrible hatred towards the entire Spanish nation and everything that is decided and decreed in Brussels and Madrid,' Requesens observed. ${ }^{77}$

In his memoirs, Champagney offers us an example of how Sancho Dávila had in earlier years allowed soldiers to enter into the city without his express permission through the special gate on the outside of the citadel. This had happened, for example, after the victory of Sancho at the Battle of Mook in 1574, with Spanish soldiers loudly celebrating in the streets. There is also the story that Sancho had long been waiting for an opportunity to attack the city and rob it of its riches. This, according to Champagney, had almost led to a duel between Sancho and fellow commander Julián Romero. ${ }^{78}$ So, besides fear and mistrust on both sides, there was also a personal conflict that must have frustrated any further attempt at negotiation.

Another important and often overlooked element is the role of the German troops who were stationed in the city. Though modern historiography tends to describe the conflict in terms of an encounter between Spaniards and Netherlanders, we have already seen the specific animosity between the Spanish and the Walloons after the attack. The German mercenaries had been put in a difficult situation. Who were they going to support? Who was going to pay them? The personification of this problem was commander Cornelis van Eynde. As this commander of German troops was born in a village close to Brussels, Champagney called him a traitor to his patria. ${ }^{79}$ According to Rooms, three German colonels had already chosen to side with Dávila well before the attack, while colonels Eberstein and Van Eynde had declared they would remain on the side of the States-General, but then tried to surrender once the fighting had begun. ${ }^{80}$ The shifting loyalties of German mercenaries most certainly influenced the outcome of the battle within city walls, but are excluded from the description once the stories became nationalised and presented as a conflict between Spain and the Low Countries. By eliminating the presence of the German troops from the story, the idea of a mutiny gone wild gains credibility.

77 Perrenot, Mémoires, xxv, xxxii-xxxiii: 'Sancho D'Avila, sans faire tort à personne, est le meilleur soldat que le Roi ait aux Pays-Bas, on ne peut lui reprocher que sa passion violente contre Champagney, tandis que Champagney en a une terrible contre toute la nation espagnole, contre tout ce qui se fait et s'ordonne à Bruxelles et à Madrid.'

78 Perrenot, Mémoires, 39-40, 83.

79 Perrenot, Mémoires, 149; Mackenzie, 'Study', 286, 288.

80 Rooms, 'Nieuwe visie', 48; Mendoza, Comentarios (1948), 549; Hooft, Alle de gedrukte werken, V, 470. There is also the story of the agreement between Dávila and Eberstein, supposedly signed by the German colonel in a state of drunkenness. 


\section{Furies}

An essential element in the fame of the Spanish Fury of Antwerp is its specific description as being a 'fury'. Jan van der Meulen's letter is proof that directly after the events, those from Antwerp and their family members living outside of the city were using this exact term - Spanish Fury. Ambassador Wilson, writing on 13 November 1576, however, used the word fury to describe popular sentiment in Brussels, reporting 'the furie of the people, who are in soche rage' ${ }^{81}$ On the $17^{\text {th }}$ of that same month, Wilson had a meeting with Gerónimo de Roda in Antwerp, during which the Spanish councillor blamed 'the yonge heades at Bryssels, and the furie of the people', but later on he also spoke of 'the furie of the sowldiours', referring to the behaviour of the royal troops at Antwerp. ${ }^{82}$ It shows the word could still be used in different settings. The Dutch pamphlet also uses the word fury, as do the Antwerp judicial records from 1577 concerning the punishment of some of the perpetrators who had actively taken part in the plundering, though never in a direct combination with the adjective 'Spanish' ${ }^{83}$

In this chaotic period of the history of the Low Countries, the word fury seems to have been on everybody's lips and could still refer to various groups and situations, but it would later be inextricably linked to the events of 1576 in Antwerp. Historian Emanuel van Meteren, born in Antwerp, informed his readers in 1599 that the inhabitants of Antwerp and their posterity had coined and used the name of 'Spaensche furije'. Hooft, married to a woman of Antwerp descent, did the same, writing that 'this more than gruesome event, never to be erased from their memory, is being remembered by the inhabitants of the city with the name of Spanish fury or rage' ${ }^{84}$ Within the history of warfare in the Low Countries, the term fury has evolved into a generic description of situations in which a (foreign) army uses extreme violence against the local inhabitants, though this specific meaning is not acknowledged in most dictionaries. ${ }^{85}$ Nowadays, there are at least ten violent events from the history of the Low Countries during the sixteenth century that have received the predicate of fury, often, but not exclusively, related to Spanish troops.

There is no reason why we should not continue referring to the days of plunder and violence as the Spanish Fury, as Antwerp burghers decided to at the time of the events. Nonetheless, if we continue to do so, we have to keep in mind that this choice of words was also part of a strategy by the insurgent party to put all the blame on the Spanish soldiers and avoid speaking about the origins of the events as a military confrontation between two armies. The extreme violence against civilians at Antwerp was easily attached to the ill-famed Spanish soldiers. Modern historiography has fairly recently connected the outburst of extreme violence at Antwerp to the specific group of Spanish mutineers, maybe

81 Thomas Wilson to Francis Walsingham, Brussels, 13 November 1576, in Kervyn de Lettenhove (ed.), Relations politiques, IX, 27.

82 Thomas Wilson to the Privy Council, 19 November 1576, in Kervyn de Lettenhove (ed.), Relations politiques,

IX, 41-42.

83 Génard, 'Poursuites', 41, 44, 61, 74.

84 Van Meteren, Belgische oft Nederlandsche historie, fol. 97r; Hooft, Alle de gedrukte werken, IV, 475.

85 Eekhout, 'Furies', 244. 
because the idea that all Spaniards were cruel by nature, in line with the Black Legend, no longer holds. This narrative shift makes it possible to continue seeing the Netherlanders as the innocent victims, a nation of peaceful burghers attacked by cruel Spanish soldiers: unfortunately, Hogenberg's famous engravings support this unbalanced vision. However, the mutineers were part of an army which was fighting another army. What started as a battle within city walls was then directly followed by the terrible sack of the city by both mutineers and other soldiers.

\section{Bibliography}

\section{Archival and Manuscript Sources}

Leiden University Library (UBL), ATH 182, Jan van der Meulen to Andries van der Meulen, Antwerp, 3 November 1576, UBL, ATH 1303, Henrick de Hazen to Andries van der Meulen, Antwerp, 11 November 1576.

\section{Printed Sources}

Arnade, Peter, Beggars, iconoclasts and civic patriots. The political culture of the Dutch Revolt (Ithaca 2008). Benedict, Philip, Graphic history. The 'Wars, Massacres and Troubles' of Tortorel and Perrissin (Geneva 2007). Boone, Marc, 'Destroying and reconstructing the city. The inculcation and arrogation of princely power in the Burgundian-Habsburg Netherlands $\left(14^{\text {th }}-16^{\text {th }}\right.$ centuries)', in Martin Gosman, Arjo Vanderjagt, and Jan Veenstra (eds.), The propagation of power in the medieval West (Groningen 1997) 1-33.

Boone, Marc, 'The Dutch Revolt and the medieval tradition of urban dissent', Journal of Early Modern History 11 (2007) 351-375.

Boone, Marc, 'From cuckoo's egg to "sedem tyranni". The princely citadels in the cities of the Low Countries, or the city's spatial integrity hijacked ( $15^{\text {th }}$-early $16^{\text {th }}$ centuries)', in Marc Boone and Martha C. Howell (eds.), The power of space in late medieval and early modern Europe. The cities of Italy, Northern France and the Low Countries (Turnhout 2013) 77-95.

Brieve et veritable Histoire de la prinse d'Anuers, et du cruel meurtre, embrasement de feu, et autres acte inhumains des Espagnols, le 4. iour de Nouembre, 1576 (s.l. 1577).

Buchanan, Catherine, The massacre of St. Bartholomew's (24-27 August 1572) and the Sack of Antwerp (4-7 November 1576). Print and political responses in Elizabethan England. PhD diss., London School of Economics, 2011.

Eekhout, Marianne, 'Furies in beeld. Herinneringen aan gewelddadige innames van steden tijdens de Nederlandse Opstand op zeventiende-eeuwse schilderijen', De Zeventiende Eeuw 30 (2014) 243-266.

Fagel, Raymond, 'La Furia Española (1576) en el teatro. ¿Un trágico accidente de la guerra o una agresión premeditada?', in Yolanda Rodríguez Pérez and Antonio Sánchez Jiménez (eds.), La Leyenda Negra en el crisol de la comedia. El teatro del Siglo de Oro frente a los estereotipos antihispánicos (Madrid 2016) 51-66.

Fagel, Raymond, 'Gascoigne's The Spoyle of Antwerpe (1576) as an Anglo-Dutch text', Dutch Crossing 20 (2017/2) 1-10.

Fagel, Raymond, 'La imagen de la Furia Española de Amberes (1576)', in José Ignacio Fortea Pérez, Juan Eloy Gelabert González, Roberto López Vela, and Elena Postigo Castellanos (eds.), Monarquías en conflicto. Linajes y noblezas en la articulación de la Monarquía Hispánica (Madrid 2018) 51-63 (http://hdl. handle.net/1887/9621, accessed on 1 November 2019). 
García Cárcel, Ricardo, El demonio del sur. La leyenda negra de Felipe II (Madrid 2017).

Gascoigne, George, The complete works of George Gascoigne. J.W. Cunliffe (ed.), 2 vols. (Cambridge 1910). Génard, P., 'La furie espagnole. Documents pour servir à l'histoire du Sac d'Anvers en 1576', Annales de l'Académie d’Archéologie de Belgique 32 (1876) 5-728.

Génard, P., 'Les poursuites contre les fauteurs de la furie espagnole ou du sac d'Anvers de 1576', Annales de l'Académie d'Archéologie de Belgique 35 (1879) 3-170.

Hessels, Joannes Henricus (ed.), Abrahami Ortelii et virorum eruditorum ad eundem et ad Jacobum Colium Ortelianum epistulae (Cambridge 1887).

Hooft, Pieter Corneliszoon, Alle de gedrukte werken 1611-1738, 9 vols. W. Hellinga and P. Tuynman (eds.) (Amsterdam 1972).

Horst, Daniel R., De Opstand in zwart-wit. Propagandaprenten uit de Nederlandse Opstand 1566-1584 (Zutphen 2003).

Janssens, Gustaaf, 'Brabant in het verweer'. Loyale oppositie tegen Spanje's bewind in de Nederlanden van Alva tot Farnese 1567-1578 (Kortrijk-Heule 1989).

Kervyn de Lettenhove, J. (ed.), Relations politiques des Pays-Bas et de l'Angleterre sous le règne de Philippe II, 11 vols. (Brussels 1890).

Kuijpers, Erika and Judith Pollmann, 'Why remember terror? Memories of violence in the Dutch Revolt', in Jane Ohlmeyer and M.Ó Siochrú (eds.), Ireland 1641. Contexts and reactions (Manchester 2013) 176-196.

Lancaster, William Scott, A Larum for London. A critical edition of the performative text. PhD diss., Texas A\&M University-Commerce, 2011.

Lem, Anton van der, De Opstand in de Nederlanden, 1568-1648. De Tachtigjarige Oorlog in woord en beeld (Nijmegen 2018).

Lombaerde, Piet, 'Antwerpen en zijn citadel in the picture. De onbekende prentenreeks van Johannes Portantius', HistoriANT 2 (2014) 89-116.

Mackenzie, Ann. L., 'A study in dramatic contrasts. The siege of Antwerp in A larum for London and El saco de Amberes', Bulletin of Hispanic Studies 59 (1982) 283-300.

Marnef, Guido, 'The towns and the revolt', in Graham Darby (ed.), The origins and development of the Dutch Revolt (London 2001) 84-106.

Martínez Luna, Fernando, Een ondraaglijk juk. Nederlandse beeldvorming van Spanje en de Spanjaarden ten tijde van de Opstand, 1566-1609 (Hilversum 2018).

Mendoza, Bernardino de, Comentarios de Don Bernardino de Mendoça de los sucedido en las guerras de los Países Baxos, desde el año de 1567 hasta el de 1577. Antonio Cortijo Ocaña y Gómez Moreno (ed.) (Madrid 2008).

Mendoza, Bernardino de, Comentarios de las guerras de los Países-Bajos (Madrid 1948).

Motley, John Lothrop, The rise of the Dutch Republic, 3 vols. (London 1929).

Parker, Geoffrey, 'Mutiny and discontent in the Spanish army of Flanders 1572-1607', in Geoffrey Parker, Spain and the Netherlands 1559-1659. Ten studies (London 1979).

Parker, Geoffrey, The Dutch Revolt (London 1977).

Parker, Geoffrey, 'The etiquette of atrocity', in Geoffrey Parker, Empire, War and Faith in Early Modern Europe (London 2002) 143-168.

Perrenot, Frédéric, Mémoires de Frédéric Perrenot, sieur de Champagney, 1573-1590. A.L.P. Robaulx de Soumoy (ed.) (Brussels 1860).

Peters, Emily J., Den gheheelen loop des weerelts (the whole course of the world). Printed processions and the theater of identity in Antwerp during the Dutch Revolt. PhD diss., University of California, Santa Barbara, 2005.

Pidal y Salvá, Miguel, marqués de (ed.), 'Documentos relativos á D. Sancho Dávila, general de Felipe II', in Colección de Documentos Inéditos para la Historia de España, 102 vols. (Madrid 1857), XXXI, 5-574.

Pietersma, Arend, 'Jan van der Meulen, victim of the Spanish Fury in Antwerp (1576)', https://www.leidenspecialcollectionsblog.nl/articles/jan-van-der-meulen-victim-of-the-spanish-fury-in-antwerp (Accessed on 20 March 2018). 
Pipkin, Amanda, 'They were not humans, but devils in human bodies. Depictions of sexual violence and Spanish tyranny as a means of fostering identity in the Dutch Republic', Journal of Early Modern History 13 (2009) 229-264.

Pipkin, Amanda, Rape in the Republic (Leiden 2013).

Pollmann, Judith, 'Eine natürliche Feindschaft. Ursprung und Funktion der Schwarzen Legende über Spanien in den Niederlanden, 1560-1581', in Franz Bosbach (ed.), Feindbilder. Die Darstellung des Gegners in der politischen Publizistik des Mittelalters und der Neuzeit (Cologne, Weimar, and Vienna 1992) 73-93.

Rodríguez Pérez, Yolanda, 'El amotinado como español ejemplar. Apuntes sobre El saco de Amberes de Rojas Zorrilla y Los amotinados en Flandes de Vélez de Guevara', in Eugenia Houvenaghel and Ilse Logie (eds.), Alianzas entre historia y ficción. Homenaje a Patrick Collard (Geneva 2009) 237-248.

Rojas Zorrilla, Francisco de, El saco de Amberes (s.l., s.n.).

Rooms, Etienne, 'Een nieuwe visie op de gebeurtenissen die geleid hebben tot de Spaanse Furie te Antwerpen op 4 november 1576, Bijdragen tot de Geschiedenis 54 (1971) 31-55.

Santiago Belmonte, Beatriz, 'The year of the Furies. Military correspondence around the Sack of Antwerp (1576)', in Raymond Fagel, Leonor Álvarez Francés, and Beatriz Santiago Belmonte (eds.), Early modern war narratives and the Revolt in the Low Countries (Manchester 2020) 56-73.

Sanz Camanes, Porfirio, 'Las relaciones entre el teatro y la política en la creación de imágenes y propaganda sobre Flandes en la España del Barroco', in Francisco José Aranda Pérez (ed.), La declinación de la Monarquía Hispánica en el siglo XVII (Cuenca 2004) 957-989.

Sherer, Idan, "'All of us, in one voice, demand what's owed us". Mutiny in the Spanish infantry during the Italian Wars, 1525-1538', Journal of Military History 78 (2014) 893-926.

Soen, Violet, ¿¿Más allá de la leyenda negra? Léon van der Essen y la historiografía reciente en torno al castigo de las ciudades rebeldes en los Países Bajos (siglos XIX a XVI)', in Léon van der Essen, El ejército español en Flandes, 1567-1584. Gustaaf Janssens (ed.) (Cuacos de Yuste 2008) 45-72.

Trillo, Antonio, Historia de la rebelión y guerras de Flandes. Miguel Echevarría Bacigalupe (ed.) (Viena 2003).

Van Meteren, Emanuel, Belgische oft Nederlandsche historie van onsen tijden (Delft: Jacob Cornelisz Vennecool, 1599).

Vázquez de Prada, Valentín (ed.) Lettres marchandes d’Anvers. Affaires et gens d’affaires, 4 vols. (Paris 1960).

Verheul, Jaap, De Atlantische pelgrim. John Lothrop Motley en de Amerikaanse ontdekking van Nederland (Amsterdam 2017).

Voges, Ramon, 'Macht, Massaker und Repräsentationen. Darstellungen asymmetrischer Gewalt in der Bildpublizistik Franz Hogenbergs', in Jörg Baberowski and Gabriele Metzle (eds.), Gewalträume. Soziale Ordnungen im Ausnahmezustand (Frankfurt 2012) 29-69.

Voges, Ramon, 'Power, faith, and pictures. Frans Hogenberg's account of the Beeldenstorm', BMGN/Low Countries Historical Review 131 (2016) 121-140.

Voges, Ramon, Das Auge der Geschichte. Der Aufstand der Niederlande und die Französischen Religionskriege im Spiegel der Bildberichte Franz Hogenbergs (ca. 1560-1610) (Leiden 2019).

Warachtige beschrijvinghe van het innemen van Antwerpen ende vande onmenschelijcke ende gants grouwelicke moort, brandt, plonderinge, ongehoorde vrouwen cracht ende maechden schenderye by den Spaniaerden ende haren aenhanck den 4. Novembris anno 1576, ende eenige dagen daerna, aldaer bedreven, ghestelt door een die daer selfs teghenwoordich gheweest is (s.l. 1576).

Warhaffige und erbermliche Zeitung von dem Unmenschlichen und gantz grewlichem Mord, Brand, Plündern, auch unerhortem Frauwenschenden und bekreffigungen, so die von Antorff den 4 Novembris, in diesem 1576 Jar, von den Spaniern gar erbermlich erlitten haben (Cologne 1576). 